\title{
INVESTIGATING THE E-LEARNING READINESS OF GHANAIAN PARENTS DURING COVID-19
}

\author{
Naa Kai Amanor-Mfoafo ${ }^{1 i}$, \\ Olivia Akrofi' ${ }^{2}$, \\ Kwamina Kurefi Edonu ${ }^{3}$, \\ Ebenezer Nortei Dowuona ${ }^{4}$ \\ ${ }^{1}$ Noyam Publishers, \\ Accra, Ghana \\ ${ }^{2}$ Kwame Nkrumah University of Science and \\ Technology Primary School, \\ Kumasi, Ghana \\ ${ }^{3}$ University of Mines and Technology, \\ Tarkwa, Ghana \\ ${ }_{4}^{4}$ University of Professional Studies, \\ Accra, Ghana
}

\begin{abstract}
:
In recent times, the Coronavirus (COVID-19) pandemic has led to unprecedented changes in the livelihood of mankind globally bringing most socio-economic activities to a standstill. The Education sector is not exempted. With the current closure of schools to contain the spread of the virus, this study sought to investigate the readiness of Ghanaian parents to support their children with e-learning while at home. Using a survey research method, parents of children in primary one to six responded to a questionnaire. Data collected from 113 parents were analyzed. The study used a factor analysis to analyze the factors influencing parental readiness. The findings indicated that parents with a high socio-economic status were more prepared to assist children with e-learning as compared to parents with low socio-economic status during COVID-19. It is being recommended that schools invest more resources in conducting e-learning training sessions for parents. The study contributes to ongoing discussions on COVID-19 and Education.
\end{abstract}

Keywords: E-learning readiness, Corona Virus (COVID-19), basic school, socio-economic status (SES)

\footnotetext{
i Correspondence: email naakaiam@noyam.org
} 


\section{Introduction}

A major effect of the Corona Virus (COVID-19) pandemic has been the closure of educational institutions by most governments worldwide to contain the spread. By the end of March 2020, all schools were closed in many countries worldwide. Weeden and Cornwell (2020) are of the view that social distancing is prudent in reducing person-toperson contact to minimize community spread of the pandemic. An estimated 862 million children and young people representing almost half of the student population in 107 countries globally have been affected (UNESCO, 2020).

On March 15, 2020, Nana Addo Danquah Akuffo-Addo (President of Ghana) gave his second address to the nation on his Government's response to COVID-19. As part of measures to contain the spread of the pandemic, he ordered the closure of all public and private educational institutions in Ghana (MyJoyOnline, 2020). He further issued a directive to the Ministry of Education and the Ministry of Communication to roll out distance learning programs for students. The president in his $10^{\text {th }}$ address to the nation stated that: "all other educational facilities, private and public, for non-final year students, will remain closed until further notice." He however announced the re-opening of schools and universities to allow final-year junior high, senior high, and university students to resume classes ahead of the conduct of their respective exit examinations. This implies that most children would still remain home until further directives for schools to reopen.

However, it behooves parents to motivate their children to learn at home, whilst making use of distance learning resources provided by schools. UNESCO reports (2020) have argued that this may be quite challenging for parents with low socio-economic status (SES). Furthermore, parents may absent themselves from work to cater for their children. This can have serious repercussions on their productivity and income. Globally, the educational sector has swiftly embarked on e-learning, shifting from traditional direct teaching and learning to the use of e-learning systems.

Comparing Ghana to other developed countries it is evident that many schools in such countries have adequate infrastructure and practices for e-learning programs, hence their readiness to move to teaching and learning online was not farfetched. OwusuFordjour et al. (2020), mentioned that most tertiary institutions in Ghana have adopted some e-learning practices to facilitate learning as they launched Learning Management Systems (LMS) for the continuation of teaching and learning. Before the directive, Ghanaian universities such as Kwame Nkrumah University of Science and Technology (KNUST), University of Ghana (UG), University of Cape Coast (UCC) and University of Education Winneba (UEW) had programs administered through e-learning (Hatsu \& Asamoah, 2020). However, the Ministry of Education has advanced its efforts to help pretertiary schools in the country embark on e-learning ensuring teaching and learning while learners stay at home. The National Inspectorate Board (NIB) in collaboration with the Ministry of Education in May 2020 also issued an e-learning guideline for pre-tertiary schools to use in implementing either commercial, free, open-source or cloud-based LMS.

The Ministry of Education additionally rolled out learning programs on media such as radio, television and online with support from the Ministry of Communications 
and Ministry of Information (GraphicOnline, 2020). The Ministry in collaboration with the Centre for National Distance Learning and Open Schooling (CENDLOS) currently delivers a daily TV broadcast on educational content for pupils from Kindergarten (KG) to Senior High School (SHS). These initiatives are laudable but leave parents with the responsibility of ensuring that their wards fully participate in e-learning exercises during this period. This study therefore seeks to investigate the extent to which parents are prepared to support their children with e-learning and the factors that affect their readiness focusing on Ghanaian parents of basic school children in primary one to six.

\section{Literature Review}

\subsection{Coronavirus(COVID-19) Pandemic}

The first case of the novel coronavirus (COVID-19) was recorded on December, $1^{\text {st }} 2019$ in Wuhan a city in China (Lai et al., 2020). Increasingly, by the 30 th of December, 2019 the World Health Organization (WHO) office in Beijing had received reports of a cluster of pneumonia patients. Clinically, the presentation showed a shared viral strain of pneumonia named 2019 Ncov or 2019 novel coronavirus. This caused health authorities to raise an alert prompting WHO to declare a state of health emergency globally. COVID19 has affected and led to the death of many people in countries worldwide. It is significant to note that the COVID-19 pandemic is not the first time the Education Sector has considered e-learning or distance learning as an option for crisis (Murphy, 2020). In fall 2009, the United States of America experienced the outbreak of Influenza A virus, a subtype H1N1 where the contingency plans included substitution of online classes. Records on COVID-19 in Ghana as at the $31^{\text {st }}$ of May, 2020 indicated the following: number of positive cases: 8070; recovered cases: 2947; deaths: 36; severely ill: 36 (MyJoyOnline, 2020). As the COVID-19 pandemic persists with new cases being recorded daily. It is uncertain when schools would fully be re-opened.

\subsection{E-Learning}

The Education sector globally has made use of Electronic Learning (E-learning) for basic, secondary and higher education. There is an ongoing debate on a suitable definition for e-learning. Recently, the impact of technology on education and pedagogical methods have outlined a new focus to the debate (Perraton, 2002). With the new focus, Algahtani (2011) defined e-learning based on distance learning, technological and pedagogical perspectives. From the distance learning perspective, e-learning has been defined as a learning process in which majority of the teaching is conducted by an instructor distant from the learner. With the technological and pedagogical perspective, distance learning incorporates the supervision of educational institutions, where multimedia serves as the main resource to support self-directed learning synchronously or asynchronously.

E-learning is characterized by a varied approach to delivery, making use of computer network technology, internet, intranets, extranets, satellite broadcasts, audio/videotapes, interactive TV, CD-ROMs, etc. E-learning can also be delivered through a Learning Management System (LMS) either presented by the institutions or 
free to use sites on the internet (NIB Guidelines, 2020). Research has shown that this mode of learning has been well utilized in developed nations globally. It can be considered the standard form of delivery for distance education programs in post-secondary institutions in more economically advanced countries (Bates, 2015). McGill \& Klobas, 2009 discovered that $95 \%$ of higher education institutes in the United Kingdom make use of LMSs for teaching and learning. Examples of free LMS for e-learning include Google Classroom, Moodle, ClassDojo (which allows one to sign-up as a parent, teacher, student or school leader), Canvas, Blackboard course sites, and Sakai CLE just to mention a few. E-learning can be delivered using the following instructional formats: Interactive E-lessons PowerPoint Presentations; Images-Animations and Blogs; Audio - Webinar \& Virtual Classroom, Shared Documents; Role Play-Video Conferences and Photos (NIB Guidelines, 2020).

Many researchers recommend e-learning as a very useful tool for distance education. It is an easy way to reduce both students and lecturers commuting to and fro their places of residence and their learning institutions (Yakubu \& Dasuki, 2018). The quality of teaching through e-learning to a large extent is dependent on the nature and superiority of the e-learning systems used (Yakubu \& Dasuki, 2018; Balash et al., 2011).

Adoption and Implementation of e-learning have been widely studied in recent years. Among many pieces of research carried out, researchers have explored obstacles hindering the full adoption and implementation of e-learning in developing and advanced countries. So \& Swatman (2005), used a factor analysis to determine the factors influencing the e-learning readiness of teachers in Hong Kong. The factors discovered included: learners' Preparedness; Teachers' Preparedness; IT Infrastructure; Management Support; School Culture and Preference to meet face-to-face. The Ghana Education Service (GES), through its new educational policy, emphasizes the importance of technology-based pedagogy in the school curriculum. Similarly using a multistakeholder approach, Ansong et al. (2017) used a factor analysis to discover and explore the technological, organizational, and environmental determinants of e-learning adoption in the University of Ghana. Their findings indicated some disparities in the adoption factors for the three e-learning stakeholders (students, instructors, and administrators). In discussing the impact of COVID-19 on learning among Ghanaian students, Owusu-Fordjour et al (2020) surveyed 250 students in tertiary and second cycle institutions in Ghana. Results from the study indicated that e-learning platforms rolled out in Ghana also posed challenges to many students due to limited internet access and low IT competency in using these technological devices. Their study recommended that students and teachers alike be introduced to e-learning platforms to enable effective usage for teaching and learning. These studies solely focused on the teachers and learners but did not fully discuss the role of parents in ongoing transition from face-to-face teaching to e-learning.

\subsection{E-learning Readiness}

Several models on e-learning readiness have been used in different studies worldwide. Examples of models include the Chapnick's Model (2000); Borotis and Poulymenakou's 
model (2004); Bakry's STOPE model (2007); Li-An Ho's model (2009); Chai Lee et al's Model (2009) amongst others. Each of the mentioned models provides a set of factors that can be used to measure e-learning readiness. Technological, Financial, and Psychological factors are predominant in all the models. A major drawback of these models is that they are perfect for measuring e-learning readiness in business organizations and higher educational institutions. However, in this study, the researchers take a queue from the predominant factors to measure e-learning readiness in basic schools focusing on parents as major stakeholders of the e-learning process.

Since the Government directed the closure of all educational institutions due to the COVID-19 pandemic, a few public and private basic schools in Ghana have devised strategies for the progress of teaching and learning for students. The Ministry of Education has embarked on teaching and learning on television in addition to other forms of e-learning adopted by schools to address the situation (Mohammed, 2020). In some schools, teachers have been trained to use different electronic devices to engage learners at both basic and secondary levels to enable them to complete the academic calendar. However, there are challenges involved in the new pedagogy. Not all schools have computer laboratories as well as teachers who are conversant with ICT tools. Not all learners have computers and smartphones readily available for online teaching and learning. Not all parents have the resources and technical knowledge to support their wards with e-learning. These pedagogies are novel to many schools and learners.

On parental readiness Akrofi, (2020) posits that a lack of parental support has a negative influence on the academic performance of students. Good parenting skills become critically important whenever children are confined within the boundaries of the home. Parents can study the behaviour of their children to detect or identify issues related to psychological and physical growth in a period of social distancing and isolation. Also, some parents with high socio-economic status (SES) have opted for homeschooling to help their children learn at home (Mohammed, 2020). Many have raised fears that parents with little or no education may have their children stay home with little or no learning. In addition, children from low SES backgrounds may be unable to partake in e-learning as most online study platforms are accessible through electronic gadgets such as TV, computers, smartphones and the availability of internet data.

\section{Methodology}

Using a survey research design, questionnaires were delivered to 150 parents to collect data. The questionnaires were administered online using Google forms from June to July 2020 using a purposive sampling technique. Only parents of learners in primary one to six were contacted. These parents were targeted because of the prolonged effect of the mandatory shutdown of schools due to COVID-19. 117 of the questionnaires were completed with 113 valid. The questionnaire consisted of 2 sections having 23 questions in total. The first section comprised close-ended questions on the respondent's demographic data and ownership of electronic gadgets to support e-learning in their homes. In the second section the respondents were asked to indicate their agreement or 
disagreement with several statements using a 4-point Likert-type scale ranging from Strongly agree -1; Agree -2; Disagree -3; Strongly Disagree -4.

\subsection{Data Analysis}

Gathered data was analyzed using Statistical Package for the Social Sciences (SPSS version 20.0). 113 questionnaires were analyzed. Specifically, descriptive statistics, reliability analysis, one-way analysis of variance (ANOVA), factor analysis, and principal component factor analysis were used to analyze the data.

\section{Results and Discussion}

\subsection{Results}

The results from the data analyzed are presented in Table 1, 2, 3. Tables 4 and 5 present the results of the factor analysis.

\subsubsection{Demographic Characteristics of Respondents}

The background information reflects the vital attributes of the population which forms the basis under which the researchers obtained pertinent data. Table 1 below shows the demographic analysis of the respondents.

Table 1: Demographic Characteristics of Respondents

\begin{tabular}{|c|c|c|}
\hline Items & Frequency & Percent \\
\hline \multicolumn{3}{|l|}{ Age Group } \\
\hline Below 30yrs & 14 & $12.4 \%$ \\
\hline $30-40 \mathrm{yrs}$ & 57 & $50.4 \%$ \\
\hline $41-50 \mathrm{yrs}$ & 40 & $35.4 \%$ \\
\hline $51-60 \mathrm{yrs}$ & 2 & $1.8 \%$ \\
\hline \multicolumn{3}{|l|}{ Level of Education } \\
\hline High School & 13 & $11.5 \%$ \\
\hline Diploma & 10 & $8.8 \%$ \\
\hline Bachelor's Degree & 42 & $37.2 \%$ \\
\hline Master's Degree & 45 & $39.8 \%$ \\
\hline $\mathrm{PhD}$ & 3 & $2.7 \%$ \\
\hline \multicolumn{3}{|c|}{ Occupation of Respondents } \\
\hline Teacher & 37 & $32.7 \%$ \\
\hline Engineer & 5 & $4.4 \%$ \\
\hline Self Employed & 2 & $1.8 \%$ \\
\hline Reverend Minister & 1 & $.9 \%$ \\
\hline Accountant & 2 & $1.8 \%$ \\
\hline Others & 66 & $58.4 \%$ \\
\hline \multicolumn{3}{|c|}{ Type of School Attended by Children } \\
\hline Public & 28 & $24.8 \%$ \\
\hline Private & 85 & $75.2 \%$ \\
\hline \multicolumn{3}{|l|}{ Region } \\
\hline Greater Accra & 53 & $46.9 \%$ \\
\hline Ashanti & 35 & $31.0 \%$ \\
\hline Eastern & 4 & $3.5 \%$ \\
\hline
\end{tabular}




\begin{tabular}{|l|c|c|}
\hline \hline Western & 10 & $8.8 \%$ \\
\hline Bono East & 1 & $0.9 \%$ \\
\hline Volta & 3 & $2.7 \%$ \\
\hline Central & 1 & $0.9 \%$ \\
\hline Savanna & 3 & $2.7 \%$ \\
\hline
\end{tabular}

Source: Field Data, 2020.

As illustrated in table 1 above, about $50.4 \%$ of the respondents were aged between $30-40$ years, $35.4 \%$ were aged between $41-50$ years, $12.4 \%$ were aged below 30 years and $1.8 \%$ were aged between 51-60 years. The respondents were gathered from 9 out of the 16 regions in Ghana with 77.9\% from Greater Accra and Ashanti Regions of Ghana. 24.8\% had their children attending public basic schools and $75.2 \%$ attending private basic schools. The results also indicated that $11.5 \%$ of the respondents are educated to high school level. $8.8 \%$ of the respondents had a diploma, $37.2 \%$ had a bachelor's degree while $39.8 \%$ had a master's degree. Only $2.7 \%$ of the respondents have attained Ph.D. or doctorate degree.

Concerning the occupational distribution of the respondents, about $32.7 \%$ of the total number of respondents were teachers, $4.4 \%$ were engineers. $1.8 \%$ were selfemployed, $1.8 \%$ were accountants while $58.4 \%$ representing the highest number engaged in other occupations such as farming, Graphic designing, trading, marketing, etc.

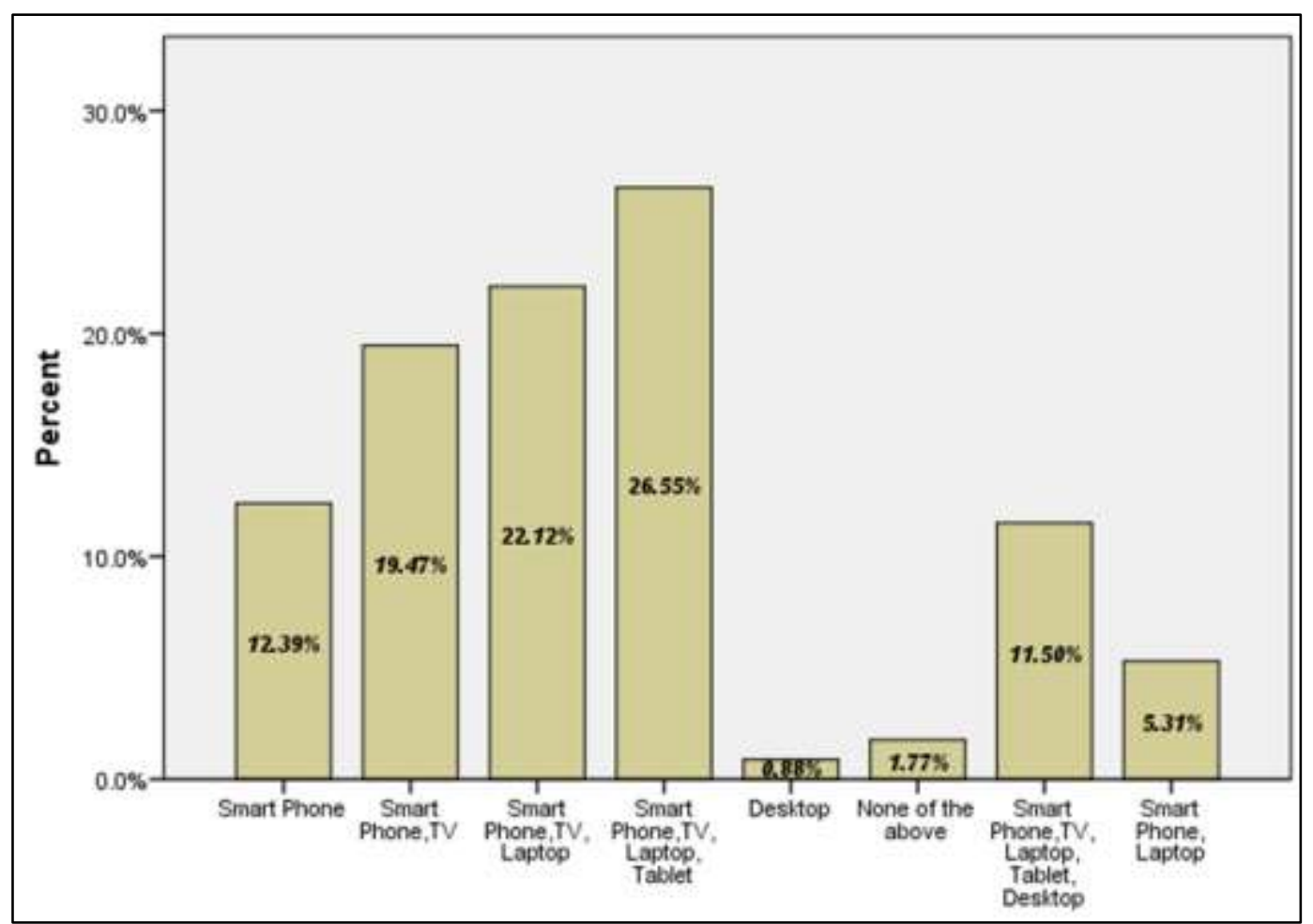

Figure 1: Graphical Presentation of Respondents' E-Learning Gadgets at Home

\subsubsection{E-Learning Gadgets Available at Home}

Figure 1 above showed the graphical presentation of respondents' gadgets at home to support e-learning. The study showed that a good number of the sampled respondents 
$(26.55 \%)$ have the following sets of e-learning gadgets at home: smartphone, television, laptop, and tablet. $22.12 \%$ have smartphones, television, and a laptop without a tablet, $19.47 \%$ of the total number of respondents have a smartphone and television, while $12.39 \%$ of the respondents were found to have only smartphones. The results also established that $11.5 \%$ of the respondents have smartphones, television, laptop, tablet, and a desktop, $5.31 \%$ have a smartphone and a laptop. However, $0.88 \%$ of the respondents were found to have only desktops while the remaining $1.77 \%$ were found to have none of the above-mentioned gadgets.

It can be implied from the above results therefore that a huge number of the respondents (approximately about 97\%) have at least smartphones in their homes to allow their children to participate in e-learning exercises during COVID-19.

\subsubsection{Reliability and Validity Analysis}

Creswell (2012), indicates that to conduct a study that is void of false prediction and to ensure more credible and reliable findings, it is important to analyze the reliability and validity of the individual instruments identified to measure the variables. Based on this, the reliability of the research instrument used was conducted using Cronbach's alpha coefficient. Table 2 below, presents the results of the reliability analysis.

Table 2: E-Learning Readiness of Ghanaian Parents during Covid-19

\begin{tabular}{|c|c|c|}
\hline Items & $\begin{array}{l}\text { CA if Item } \\
\text { Deleted }\end{array}$ & CA \\
\hline 1. I know about e-learning & .749 & \multirow{12}{*}{.778} \\
\hline $\begin{array}{l}\text { 2. I support the use of e-learning at home to teach my children during COVID- } \\
19\end{array}$ & .750 & \\
\hline $\begin{array}{l}\text { 3. My children receive exercises and assignments from their school through } \\
\text { Learning Management Systems (LMSs) such as Moodle, Class Dojo, Google } \\
\text { Classroom, Blackboard, etc. }\end{array}$ & .768 & \\
\hline $\begin{array}{l}\text { 4. I have the IT competency to enable me to assist my children with using } \\
\text { Learning Management Systems }\end{array}$ & .742 & \\
\hline $\begin{array}{l}\text { 5. My job allows me to make time to help my children with } \\
\text { e-learning }\end{array}$ & .750 & \\
\hline 6. I spend less than an hour each day assisting my children with e-learning & .772 & \\
\hline $\begin{array}{l}\text { 7. I can afford to pay a home tutor to assist my children with } \\
\text { e-learning }\end{array}$ & .771 & \\
\hline $\begin{array}{l}\text { 8. I have adequate Internet access in my home to support } \\
\text { e-learning }\end{array}$ & .769 & \\
\hline $\begin{array}{l}\text { 9. I have the technological devices (mobile phone, laptop, TV) to support } \\
\text { e-learning at home }\end{array}$ & .756 & \\
\hline $\begin{array}{l}\text { 10. I am aware of the online learning platform launched by the Ministry of } \\
\text { Education }\end{array}$ & .769 & \\
\hline $\begin{array}{l}\text { 11. I make use of this platform made available by the ministry of education to } \\
\text { supplement teaching my children }\end{array}$ & .780 & \\
\hline $\begin{array}{l}\text { 12. I have contacts with teachers to enable them to explain e-learning concepts } \\
\text { to me }\end{array}$ & .768 & \\
\hline
\end{tabular}

Source: Field Data, 2020. 
A research instrument is considered reliable if its reliability statistics, specifically the Cronbach's alpha coefficient is at least 0.7 (Hair et al.2012). The Cronbach's alpha (CA) coefficient of .778 as indicated in Table 2 above suggested that effective, credible and reliable items have been identified to measure the extent to which Ghanaian parents are prepared to supports their children in e-learning and the challenges involved. The results also suggested that almost all the individual instruments are relevant to the study and therefore none of them should be eliminated in conducting the main analysis since the deletion of any will reduce the Cronbach's alpha coefficient.

\subsubsection{Main Findings}

Descriptive statistics (frequency and mode) were employed to analyze the data collected concerning e-learning readiness of Ghanaian parents during COVID-19. The results are presented in Table 3 below.

Table 3: Perceived e-learning readiness of Ghanaian Parents during COVID-19

\begin{tabular}{|c|c|c|c|c|}
\hline Items & $\begin{array}{l}\text { SA } \\
\text { F } \%\end{array}$ & $\begin{array}{c}\text { A } \\
\text { F } \%\end{array}$ & $\begin{array}{c}\mathrm{D} \\
\mathrm{F} \%\end{array}$ & $\begin{array}{l}\mathrm{SD} \\
\mathrm{F} \%\end{array}$ \\
\hline I know about e-learning. & $\begin{array}{c}8 \\
7.08 \\
\end{array}$ & $\begin{array}{c}6 \\
5.31 \\
\end{array}$ & $\begin{array}{c}34 \\
30.09 \\
\end{array}$ & $\begin{array}{r}65 \\
57.52 \\
\end{array}$ \\
\hline $\begin{array}{l}\text { I support the use of e-learning at home to teach my children } \\
\text { during COVID-19. }\end{array}$ & $\begin{array}{c}7 \\
6.19 \\
\end{array}$ & $\begin{array}{c}11 \\
9.73 \\
\end{array}$ & $\begin{array}{c}34 \\
30.09 \\
\end{array}$ & $\begin{array}{c}61 \\
53.98 \\
\end{array}$ \\
\hline $\begin{array}{l}\text { My children receive exercises and assignments from their school } \\
\text { through Learning Management Systems (LMSs) such as } \\
\text { Moodle. Class Doio Google Classroom. Blackboard etc. }\end{array}$ & 25 & 14 & 25 & 49 \\
\hline $\begin{array}{l}\text { I have the IT competency to enable me to assist my children with } \\
\text { using Learning Management Systems. }\end{array}$ & $\begin{array}{c}15 \\
13.27\end{array}$ & $\begin{array}{c}13 \\
11.50\end{array}$ & $\begin{array}{c}29 \\
25.66\end{array}$ & $\begin{array}{r}56 \\
49.56\end{array}$ \\
\hline $\begin{array}{l}\text { My job allows me to make time to help my children } \\
\text { with e-learning. }\end{array}$ & $\begin{array}{c}25 \\
22.12\end{array}$ & $\begin{array}{c}26 \\
23.01\end{array}$ & $\begin{array}{c}32 \\
28.32\end{array}$ & $\begin{array}{c}30 \\
26.55\end{array}$ \\
\hline $\begin{array}{l}\text { I spend less than an hour each day assisting my children } \\
\text { with e-learning. }\end{array}$ & $\begin{array}{c}32 \\
28.32 \\
\end{array}$ & $\begin{array}{c}33 \\
29.20 \\
\end{array}$ & $\begin{array}{c}26 \\
23.01 \\
\end{array}$ & $\begin{array}{c}22 \\
19.47 \\
\end{array}$ \\
\hline $\begin{array}{l}\text { I can afford to pay a home tutor to assist my children } \\
\text { with e-learning. }\end{array}$ & $\begin{array}{c}24 \\
21.24\end{array}$ & $\begin{array}{c}26 \\
23.01\end{array}$ & $\begin{array}{c}38 \\
33.63\end{array}$ & $\begin{array}{c}25 \\
22.12\end{array}$ \\
\hline $\begin{array}{l}\text { I have adequate Internet access in my home to support } \\
\text { e-learning. }\end{array}$ & $\begin{array}{c}21 \\
18.58\end{array}$ & $\begin{array}{c}22 \\
19.47\end{array}$ & $\begin{array}{c}44 \\
38.94\end{array}$ & $\begin{array}{c}26 \\
23.01\end{array}$ \\
\hline $\begin{array}{l}\text { I have the technological devices (mobile phone, laptop, TV) } \\
\text { to support e-learning at home. }\end{array}$ & $\begin{array}{c}4 \\
3.54 \\
\end{array}$ & $\begin{array}{c}15 \\
13.27\end{array}$ & $\begin{array}{c}29 \\
25.66 \\
\end{array}$ & $\begin{array}{r}65 \\
57.52\end{array}$ \\
\hline $\begin{array}{l}\text { I am aware of the online learning platform launched } \\
\text { by the Ministry of Education. }\end{array}$ & $\begin{array}{c}6 \\
5.31 \\
\end{array}$ & $\begin{array}{c}18 \\
15.93 \\
\end{array}$ & $\begin{array}{c}33 \\
29.20 \\
\end{array}$ & $\begin{aligned} 56 \\
49.56\end{aligned}$ \\
\hline $\begin{array}{l}\text { I make use of this platform made available by the ministry } \\
\text { of education to supplement teaching my children. }\end{array}$ & $\begin{array}{c}38 \\
33.63\end{array}$ & $\begin{array}{c}16 \\
14.16\end{array}$ & $\begin{array}{c}34 \\
30.09 \\
\end{array}$ & $\begin{array}{c}25 \\
22.12 \\
\end{array}$ \\
\hline $\begin{array}{l}\text { I have contacts with teachers to enable them to explain } \\
\text { e-learning concepts to me. }\end{array}$ & $\begin{array}{c}25 \\
22.12\end{array}$ & $\begin{array}{c}19 \\
16.81\end{array}$ & $\begin{array}{c}38 \\
33.63\end{array}$ & $\begin{array}{c}31 \\
27.43\end{array}$ \\
\hline
\end{tabular}

Source: Field Data, 2020.

Table 3 above showed that $87.61 \%$ of the respondents do not know about e-learning, while $12.39 \%$ of the respondents agreed that they know about e-learning. Also, $84.07 \%$ 
of the respondents against $15.92 \%$ do not support the use of e-learning to teach their children at home. Concerning the respondents' children who receive exercises and assignments from their school through Learning Management Systems such as Moodle, ClassDojo, Google Classroom, Blackboard, etc., 34.61\% of the respondents agreed that their wards received exercises and assignments through the various Learning Management Systems (ClassDojo, Google Classroom, Moodle, Blackboard, etc.). However, $65.48 \%$ of the respondents disagreed. $75.22 \%$ of the total number of respondents do not have the IT competency to enable them assist their children using Learning Management Systems, while $24.77 \%$ of the respondents confirmed that they have the IT competency to assist their children in using Learning Management Systems. The jobs of $45.13 \%$ of the respondents as shown in table 3 above allow them to make time to help their children with e-learning. However, $54.87 \%$ of the respondents do not have time to help their children due to the nature of their job. Also, the results indicated that $57.52 \%$ of the respondents agree that they spend less than an hour each day assisting their children with e-learning. Nonetheless, $42.48 \%$ of the respondents disagreed with the statement. $44.25 \%$ of the respondents agree that they can afford to pay a home tutor to assist their children with e-learning, however, $55.75 \%$ of the respondents disagreed with the statement. The results also revealed that $61.95 \%$ of the respondents do not have adequate internet access in their homes to support e-learning. While $38.05 \%$ have adequate internet access to help their children at home. Again, 52.21\% of the respondents did not utilize any of the online learning platforms launched the Ministry of Education.

\subsubsection{Factors Influencing the E-learning Readiness of Ghanaian Parents}

The study sought to identify the factors influencing the respondents' readiness for elearning. To achieve this, a Principal Component Factor Analysis in SPSS version 20 was employed to extract factors. Varimax rotation with the Kaiser Normalization method was used. Individual loading of 0.53 or greater was used in factor designation.

Table 4: Factor Loadings of E-learning Readiness of Ghanaian Parents

\begin{tabular}{|c|c|c|c|c|}
\hline Items & Factor 1 & Factor 2 & Factor 3 & Factor 4 \\
\hline $\begin{array}{l}\text { 4. I have the IT competency to enable me to assist my } \\
\text { children with using Learning Management Systems. }\end{array}$ & .813 & & & \\
\hline 1. I know about e-learning. & .779 & & & \\
\hline $\begin{array}{l}\text { 9. I have the technological devices (mobile phone, } \\
\text { laptop, TV) to support e-learning at home. }\end{array}$ & .771 & & & \\
\hline $\begin{array}{l}\text { 2. I support the use of e-learning at home to teach my } \\
\text { children during COVID- } 19 \text {. }\end{array}$ & .544 & & & \\
\hline $\begin{array}{l}\text { 8. I have adequate Internet access in my home to } \\
\text { support e-learning. }\end{array}$ & .543 & & & \\
\hline $\begin{array}{l}\text { 11. I make use of this platform made available by the } \\
\text { ministry of education to supplement teaching my } \\
\text { children. }\end{array}$ & & .800 & & \\
\hline $\begin{array}{l}\text { 10. I am aware of the online learning platform } \\
\text { launched by the Ministry of Education. }\end{array}$ & & .611 & & \\
\hline
\end{tabular}




\begin{tabular}{|c|c|c|c|}
\hline $\begin{array}{l}\text { 5. My job allows me to make time to help my children } \\
\text { with e-learning. }\end{array}$ & .596 & & \\
\hline $\begin{array}{l}\text { 7. I can afford to pay a home tutor to assist my } \\
\text { children with e-learning. }\end{array}$ & & .825 & \\
\hline $\begin{array}{l}\text { 6. I spend less than an hour each day assisting my } \\
\text { children with e-learning. }\end{array}$ & & .583 & \\
\hline $\begin{array}{l}\text { 12. I have contacts with teachers to enable them to } \\
\text { explain e-learning concepts to me. }\end{array}$ & & & .851 \\
\hline $\begin{array}{l}\text { 3. My children receive exercises and assignments from } \\
\text { their school through Learning Management Systems } \\
\text { (LMSs) such as Moodle, Class Dojo, Google } \\
\text { Classroom, Blackboard, etc. }\end{array}$ & & & .793 \\
\hline \multicolumn{4}{|l|}{$\begin{array}{l}\text { Extraction Method: Principal Component Analysis. } \\
\text { Rotation Method: Varimax with Kaiser Normalization. }\end{array}$} \\
\hline
\end{tabular}

Four factors with Eigenvalues equal to or greater than one were extracted. Interpretive labels were suggested for each of these factors according to their characters as seen in Table 5 below.

Table 5: Factors Extracted by SPSS with Interpretative Labels

Factor 1: Technological Preparedness

- I know about e-learning

- I support the use of e-learning at home to teach my children during COVID-19

- I have the IT competency to enable me to assist my children with using Learning Management Systems

- I have the technological devices (mobile phone, laptop, TV) to support e-learning at home

- I have adequate Internet access in my home to support e-learning

Factor 2: Socio-economic Preparedness

- My job allows me to make time to help my children with e-learning

- I can afford to pay a home tutor to assist my children with e-learning

- I spend less than an hour each day assisting my children with e-learning

Factor 3: Governmental Support

- I am aware of the online learning platform launched by the Ministry of Education

- I make use of this platform made available by the ministry of education to supplement teaching my children

\section{Factor 4: School Support}

- I have contacts with teachers to enable them to explain e-learning concepts to me

- My children receive exercises and assignments from their school through Learning Management Systems (LMSs) such as Moodle, Class Dojo, Google Classroom, Blackboard, etc.

Extraction Method: Principal Component Analysis.

Rotation Method: Varimax with Kaiser Normalization.

\subsection{Discussion}

The data analyzed sampled four factors that affect the readiness of Ghanaian parents to assist their children with e-learning during the COVID-19 pandemic. The factors include Technological preparedness, Socio-economic preparedness, Governmental support and School support. So \& Swatman (2006), identified similar factors in their study which 
investigated the e-learning readiness of teachers in Hong Kong. Below is a discussion of the results and future directions for research based on the four factors sampled.

E-learning requires the use of electronic gadgets such as computers, smartphones, laptops, desktop, TV among others with an adequate supply of electricity and reliable internet access. The study results indicated that about $95 \%$ of the respondents owned at least one of the e-learning gadgets mentioned above but constant internet access was an obstruction to their usage. It was evident that about $97 \%$ of the respondents had smartphones (Fig.1). During this pandemic, both public and private schools can look at how they can effectively make use of readily available e-learning gadgets owned by both parents and teachers to support e-learning. It is very important to utilize technologies that parents are familiar with because the study results indicated that $87.61 \%$ do not know about e-learning, $75.22 \%$ do not have the IT competency to assist their children with using LMS such as (ClassDojo, Google Classroom, Moodle, Blackboard, etc.) but $84.07 \%$ support the use of e-learning at home.

Studies have shown that mobile technologies with cellular connectivity are dominant in sub-Saharan Africa. Smartphone usage in Africa is high as compared to that of developed countries (Pew Research Center, 2015). Koomson (2019), in his study, proposes the usage of WhatsApp messenger as an effective teaching tool in uploading assignments and learning materials, interacting with learners and monitoring their learning process. As most parents with smartphones use WhatsApp messenger daily school teachers can consider its usage as a teaching and learning tool. Zurek (2018), posits there were 5.60million active social media users in Ghana which represents (19\%) of the total population, with WhatsApp messenger being the most dominant social media platform. Interestingly, the proposed use of e-learning devices such as smartphones comes with its setbacks as most mobile applications for teaching and learning would require internet access for usage. The results from the study indicated that $61.95 \%$ of the respondents did not have adequate internet connectivity at home. According to Mohammed (2020), less than 50\% of the Ghanaian populace have access to the internet. Prior studies by Asibey et al. (2017) affirms that internet access in Ghana is often constrained by the high cost of internet data charges and other associated challenges such as unreliable and slow connection and unreliable power supply.

The Governmental support provided by the Ministry of Education to supplement teaching and learning of children from primary to SHS are laudable. In the study, 52.21\% of parents did not make use of learning initiatives by the Ministry of Education. This could be attributed to the time parents allocate to assist their children with learning. Most parents would have to often juggle several tasks at home whilst concentrating on their professional work. $54.87 \%$ of the respondents had jobs that did not allow them to assist their children with e-learning during the COVID-19 pandemic. Out of this number, 44.25 $\%$ were able to afford to pay a home tutor to assist their children with e-learning. This percentage can be associated with parents having a high SES. 38.93\% of parents who can be considered to be in the same category had contacts with teachers to assist them in explaining e-learning concepts. 
The National Inspectorate Board e-learning guide was released in May 2020 to support pre-tertiary schools in implementing e-learning systems. The study results show that most schools are yet to embrace the initiative as $65.48 \%$ of respondents received no exercises and assignments from schools of their wards through LMSs. However, some schools have embraced the new e-learning initiatives as $34.52 \%$ confirmed they received such exercises from schools of their wards. Evidence to support this can be seen in the case of the Kwame Nkrumah University of Science and Technology Primary School, Kumasi, Ghana. Upon the closure of schools, the School Management Board was quick to organize its teaching staff to embark on e-learning to enable the completion of the academic calendar (Akrofi, 2020). The school sent messages to parents of about one thousand and eight hundred pupils parents informing them of mandatory e-learning. Learners received videos of lessons in which teachers taught topics and gave assignments through google forms. Unfortunately, not all learners participated in this unprecedented method of teaching and learning due to lack of parental support, non-availability of elearning gadgets and inadequate internet access at home.

From the findings, the researchers argue that the non-participation of all learners in primary schools in e-learning can be attributed basically to the SES of parents. Parents with high SES are more prepared to assist their children with e-learning as compared with those with low socio-economic status. This finding agrees with Mohammed, 2020 that children are likely to continue e-learning in homes with high SES with little obstructions during COVID-19 than their counterparts from backgrounds with low SES.

\section{Recommendations}

This study was conducted within a short time frame of two months. If similar studies are carried out over a longer period of 6-8 months, it would be possible to gather more refined data on Ghanaian parents' readiness for e-learning even after COVID-19. Despite the limitations, the study recommends that schools invest more resources in conducting elearning training sessions for parents. Parents should also be encouraged to utilize the Ministry of Education online initiatives providing daily TV and radio broadcast sessions for primary school children. The study revealed that Internet access was a major issue preventing most parents from using e-learning platforms. In the interim, the researchers recommend that the Ministry of Communication should work together with the Telecommunication companies in Ghana to make Internet access readily available and cheaper throughout the COVID-19 pandemic. This would help bridge the digital divide between children from low and high SES backgrounds in using e-learning.

As Koomson (2019) has suggested, it would be necessary for schools to move towards a collective effort to make use of social messaging platforms to communicate assignments and other academic activities with students. Further studies should be conducted on utilizing Mobile learning (m-learning) leading to the development of userfriendly mobile apps to help parents teach their children.

Lastly, due to COVID-19 restrictions in movement, the study used Google forms to gather the required data. It was therefore difficult to obtain data from parents who 
were not computer literate with no internet access. Some parents contacted during the study declined to participate because they did not have the IT competency to use to Google forms. Researchers suggest that in future studies of this nature other manual data collection instruments should be considered to encourage increased participation.

\section{Conclusion}

Although Ghana has made strides to adopting e-learning in Ghana, the country is still considered to be in its early stages in using e-learning across all levels of education. The COVID-19 pandemic has brought to bear the fact that more structures and policies need to be implemented for e-learning in basic schools nationwide. This study sought to investigate the e-learning of Ghanaian parents during COVID-19. The factors that influenced the preparedness of parents were identified using factor analysis. It was evident that the parents were highly affected by the school closures during this pandemic as they need to help their children learn from home using e-learning methods. The findings suggest that parents with high SES were better poised to support their children with e-learning as compared to those with low SES. As an end to the COVID-19 pandemic is uncertain, all stakeholders in the educational sector should work towards helping learners make the most of their stay home period.

\section{About the Author(s)}

Naa Kai Amanor-Mfoafo currently works an Administrative Manager at Noyam Publishers (An Academic Research Publisher) in Accra, Ghana. She holds an MSc in Information Technology from the University of Aberdeen, UK. MBA (Management Information Systems) from Kwame Nkrumah University of Science and Technology, Ghana. She has research interests in Technology-Mediated Teaching and Learning. Email: naakaiam@noyam.org.

Olivia Akrofi is a Chief Teacher at Kwame Nkrumah University of Science and Technology (KNUST) Primary School. She holds a Master of Philosophy (Educational Innovation and Leadership Science) from KNUST, Kumasi, Ghana and a Master of Education (Guidance and Counseling) University of Cape Coast, Cape Coast, Ghana. She has research interests in Guidance and Counselling Education. Email: ooakrofi@gmail.com.

Kwamina Kurefi Edonu is the Head of the Audio Visual Unit, University of Mines and Technology. He holds a Master of Communication Design from the Kwame Nkrumah University of Science and Technology, Ghana. He has research interests in Education and Design Innovation. Email: kkedonu@umat.edu.gh.

Ebenezer Nortei Dowuona recently completed his Bachelor of Arts Degree in Business Administration from the University of Professional Studies, Accra, Ghana. He has research interests in Business Management and Information Technology. Email: dowuonaebenezer16@gmail.com. 


\section{References}

Akrofi, O. (2020). Academic Achievement of Primary School Pupils: Investigating Home Environment Factors Contributing to Low Academic Performance, E-Journal of Humanities, Arts and Social Sciences, 1(2): 49-57. https://doi.org/10.38159/ehass.2020061.

Algahtani, A. F. (2011). Evaluating the Effectiveness of the E-learning Experience in some Universities in Saudi Arabia from Male Students' Perceptions. PhD Thesis, Durham University: United Kingdom.

Asibey, B. O., Agyemang, S. \& Dankwah, B. A. (2017). The Internet Use for Health Information Seeking among Ghanaian University Students: A Cross-Sectional Study. International Journal of Telemedicine and Applications, https://doi.org/10.1155/2017/1756473.

Balash, F., Yong, Z., \& Abu, B. B. (2011). Lecturers and Educational Technology: Factors Affecting Educational Technology Adoption in Teaching. 2nd International Conference on Education and Management Technology, IACSIT Press: Singapore.

Bakry, S. H., Khalid A., \& Abdulmohsen, A. (2007). STOPE-based Approach for eReadiness Assessment Case Studies: Department of Electrical Engineering, King Saud University, Riyad, Saudi Arabia. International Journal of Network Management, 18: $65-75$.

Bates, T. (2015) Teaching in a digital age: Guidelines for designing teaching and learning. Vancouver BC: Tony Bates Associates Ltd, ISBN: 978-0-9952692-0-0.

Borotis, S. \& Poulymenakou, A. (2004). E-Learning Readiness Components: Key Issues to Consider Before Adopting e-Learning Interventions. In J. Nall \& R. Robson (Eds.), Proceedings of E-Learn 2004--World Conference on E-Learning in Corporate, Government, Healthcare, and Higher Education, pp. 1622-1629.

Chapnick, S. (2000). Are you ready for e-learning? Learning Circuits: ASTD's Online Magazine All About ELearning, https://nurhadiw.files.wordpress.com/2010/08/are you ready for elearning.pdf Retrieved $12^{\text {th }}$ August 2020.

Chai, L. G., \& Poh, Y. N. (2009). E-learning in Malaysia: Success Factors in Implementing Elearning Program, Curtin University of Technology. International Journal of Teaching and Learning in Higher Education, 20(2), pp. 237- 246.

Creswell, J. W. (2012). Research Design: Qualitative, Quantitative and Mixed Methods Approaches, 3rd ed. SAGE Publications, Inc: Thousand Oaks.

Education: From disruption to recovery, UNESCO. https://en.unesco.org/covid19/educationresponse. Accessed 20 April, 2020

Full text of Akufo-Addo's 10th address to the Nation on Coronavirus Crisis, MyJoyOnline. https://www.myjoyonline.com/news/national/full-text-of-akufoaddos-10th-address-to-the-nation-on-coronavirus-crisis/ Retrieved $2^{\text {nd }}$ June, 2020.

Ghana's fight against Covid-19 exactly a month after recording first cases, MyJoyOnline. https://www.myjoyonline.com/news/national/timeline-ghanas-fight-against- 
Naa Kai Amanor-Mfoafo, Olivia Akrofi, Kwamina Kurefi Edonu, Ebenezer Nortei Dowuona INVESTIGATING THE E-LEARNING READINESS OF GHANAIAN PARENTS DURING COVID-19

covid-19-exactly-a-month-after-recording-first-cases/ Retrieved on $13^{\text {th }}$ April, 2020.

Hair, J. F., Sarstedt, M., Ringle, C. M., Acad \& Mena, J. A. (2012). An assessment of the use of partial Least squares structural equation modeling in marketing research. Sci. 40, 414- 433. https://doi.org/10.1007/s11747-011-0261-6

Hatsu, S. \& Asamoah, E. S. (2020). Online teaching, learning and assessment: A primer for tertiary education in Ghana, MyJoyonline. https://www.myjoyonline.com/opinion/online-teaching-learning-andassessment-a-primer-for-tertiary-education-in-ghana/. Retrieved on $7^{\text {th }}$ June, 2020. Interview with Olivia Akrofi, Tutor - Kwame Nkrumah University of Science and Technology Primary School. (August 2020)

Koomson, W. K., (2019). Ontology of ubiquitous learning: WhatsApp Messenger competes successfully with learning management systems (LMS) in Ghana. International Conference Educational Technologies 2019, ISBN: 978-989-8533-83-8.

Li-An, Ho. (2009, January). The Antecedents of e-Learning Outcome: An Examination of System Quality, Technology Readiness and Learning Behaviour. Department of Educational Technology, Tamkang University, Taiwan. Adolescence, 44(175): 581599.

Lai C. C., Shih, P. T., Wo, C. W. (202.). Severe acute respiratory syndrome coronavirus 2 (SARS-CoV-2) and corona disease-2019: The epidemic and the challenges. International Journal of Antimicrobial Agent. 55 (3), 1-9.

Ministry of Education implements virtual learning - To engage students at home, Graphic Online https://www.graphic.com.gh/news/general-news/ghana-news-ministryof-education-implements-virtual-learning-to-engage-students-at-home.html.

Retrieved on $7^{\text {th }}$ June, 2020.

Murphy M. P. A. (2020).COVID-19 and emergency eLearning: Consequences of the securitization of higher education for post-pandemic pedagogy. Contemporary Security Policy, 41 (3), 492-505.

McGill, T. J \& Klobas, J. E. (2009). A task-technology fit view of learning management system impact. Journal of Computers $\mathcal{E}$ Education: 52 (1), 498-508.

Mohammed, W. F. (2020). How Covid-19 affects education for people with disabilities in Ghana, MyJoyOnline. https://www.myjoyonline.com/news/education/wunpini-fatimatamohammed-how-covid-19-affects-education-for-people-with-disabilities-inghana/. Retrieved on $10^{\text {th }}$ July, 2020.

National E-Learning Guidelines for Pre-Tertiary Schools in Ghana 2020, (Accra: National Inspectorate Board Ministry of Education, Ghana). https://www.inspectorateboard.gov.gh/nb/wpcontent/uploads/2020/05/NIBGH Elearning-Guide Final v06MAY2020.pdf

Owusu-Fordjour, C., Koomson, C. K., Hanson, D. (2020). The Impact of Covid-19 on learning -the perspective of the Ghanaian student. European Journal of Education Studies, 7 (3), 88 - 101. https://doi.org/10.5281/zenodo.3753586

Perraton, H., Creed, C., \& Robinson, B. (2002). Teacher education guidelines: Using open and distance learning, Paris: UNESCO. 
Pew Research Center, April, 2015, "Cell Phones in Africa: Communication Lifeline" Weeden, Kim A., and Benjamin Cornwell (2020). The Small-World Network of College Classes: Implications for Epidemic Spread on a University Campus. Sociological Science 7: 222-241.

So, K. K., \& Swatman, P. M. (2006). e-Learning Readiness in the Classroom: Hong Kong primary teachers. University of South Australia.

Yakubu, M. N. \& S. Dasuki (2018). Assessing eLearning systems success in Nigeria: An application of the DeLone and McLean information systems success model. Journal of Information Technology Education: Research, 17: 183-203. https://doi.org/10.28945/4077.

Zurek, K. (2018). Over 10 million Ghanaians use the internet - Report, Graphic Online. https://bit.ly/2CkvgHc Retrieved on $13^{\text {th }}$ August 2020. 
Naa Kai Amanor-Mfoafo, Olivia Akrofi, Kwamina Kurefi Edonu, Ebenezer Nortei Dowuona INVESTIGATING THE E-LEARNING READINESS OF GHANAIAN PARENTS DURING COVID-19

Creative Commons licensing terms

Author(s) will retain the copyright of their published articles agreeing that a Creative Commons Attribution 4.0 International License (CC BY 4.0) terms will be applied to their work. Under the terms of this license, no permission is required from the author(s) or publisher for members of the community to copy, distribute, transmit or adapt the article content, providing a proper, prominent and unambiguous attribution to the authors in a manner that makes clear that the materials are being reused under permission of a Creative Commons License. Views, opinions and conclusions expressed in this research article are views, opinions and conclusions of the author(s). Open Access Publishing Group and European Journal of Education Studies shall not be responsible or answerable for any loss, damage or liability caused in relation to/arising out of conflicts of interest, copyright violations and inappropriate or inaccurate use of any kind content related or integrated into the research work. All the published works are meeting the Open Access Publishing requirements and can be freely accessed, shared, modified, distributed and used in educational, commercial and non-commercial purposes under a Creative Commons Attribution 4.0 International License (CC BY 4.0). 